\title{
The multidimensional evaluation and treatment of anxiety in children and adolescents: rationale, design, methods and preliminary findings
}

\author{
Avaliação multidimensional e tratamento da ansiedade em \\ crianças e adolescentes: marco teórico, desenho, métodos e \\ resultados preliminares
}

Giovanni Abrahão Salum, ${ }^{1,2,3}$ Luciano Rassier Isolan, ${ }^{1,3}$ Vera Lúcia Bosa, ${ }^{4}$ Andrea Goya Tocchetto, ${ }^{1}$ Stefania Pigatto Teche, ${ }^{1}$ Ilaine Schuch, ${ }^{4}$ Jandira Rahmeier Costa, ${ }^{1}$ Marianna de Abreu Costa, ${ }^{1}$ Rafaela Behs Jarros, ${ }^{1,2,3,7}$ Maria Augusta Mansur, ${ }^{1,3}$ Daniela Knijnik, ${ }^{1}$ Estácio Amaro Silva, ${ }^{1,3}$ Christian Kieling, ${ }^{3}$ Maria Helena Oliveira, ${ }^{1}$ Elza Medeiros, ${ }^{1,3}$ Andressa Bortoluzzi, ${ }^{1,5}$ Rudineia Toazza, ${ }^{1,5,6}$ Carolina Blaya, ${ }^{1,7}$ Sandra Leistner-Segal, ${ }^{8}$ Jerusa Fumagalli de Salles, ${ }^{6}$ Patrícia Pelufo Silveira, ${ }^{4,5}$ Marcelo Zubaran Goldani, ${ }^{4}$ Elizeth Heldt, ${ }^{1,3}$ Gisele Gus Manfro ${ }^{1,2,3,5}$

\footnotetext{
${ }^{1}$ Anxiety Disorders Program for Child and Adolescent Psychiatry (PROTAIA), Hospital de Clínicas de Porto Alegre (HCPA), Universidade Federal do Rio Grande do Sul (UFRGS), Porto Alegre, RS, Brazil

2 National Science and Technology Institute for Child and Adolescent Psychiatry (INPD)

${ }^{3}$ Postgraduate Program in Medical Sciences: Psychiatry, Hospital de Clínicas de Porto Alegre (HCPA), Universidade Federal do Rio Grande do Sul (UFRGS), Porto Alegre, RS, Brazil

${ }^{4}$ Center for Child and Adolescent Health Studies (NESCA), Hospital de Clínicas de Porto Alegre (HCPA), Universidade Federal do Rio Grande do Sul (UFRGS), Porto Alegre, RS, Brazil

${ }^{5}$ Postgraduate Program in Neuroscience, Institute of Basic Sciences/Health (ICBS), Universidade Federal do Rio Grande do Sul (UFRGS), Porto Alegre, RS, Brazil

${ }^{6}$ Cognitive Neuropsychology Research Center (Neurocog), Universidade Federal do Rio Grande do Sul (UFRGS), Porto Alegre, RS, Brazil

${ }^{7}$ Universidade Federal de Ciências da Saúde de Porto Alegre (UFSCPA), Porto Alegre, RS, Brazil

${ }^{8}$ Medical Genetics Service, Hospital de Clinicas de Porto Alegre (HCPA), Universidade Federal do Rio Grande do Sul (UFRGS), Porto Alegre, RS, Brazil
}

\section{Abstract}

Objective: This study aims to describe the design, methods and sample characteristics of the Multidimensional Evaluation and Treatment of Anxiety in Children and Adolescents - the PROTAIA Project. Method: Students between 10 and 17 years old from all six schools belonging to the catchment area of the Primary Care Unit of Hospital de Clínicas de Porto Alegre were included in the project. It comprises five phases: (1) a community screening phase; (2) a psychiatric diagnostic phase; (3) a multidimensional assessment phase evaluating environmental, neuropsychological, nutritional, and biological factors; (4) a treatment phase, and (5) a translational phase. Results: A total of 2,457 subjects from the community were screened for anxiety disorders. From those who attended the diagnostic interview, we identified 138 individuals with at least one anxiety disorder (apart from specific phobia) and 102 individuals without any anxiety disorder. Among the anxiety cases, generalized anxiety disorder $(\mathrm{n}=95 ; 68.8 \%)$, social anxiety disorder $(\mathrm{n}=57 ; 41.3 \%)$ and separation anxiety disorder $(\mathrm{n}=49 ; 35.5 \%)$ were the most frequent disorders. Conclusion: The PROTAIA Project is a promising research project that can contribute to the knowledge of the relationship between anxiety disorders and anxiety-related phenotypes with several genetic and environmental risk factors.

Descriptors: Anxiety; Phobic disorders; Panic; Epidemiological; Comorbidity
Resumo

Objetivo: o objetivo deste estudo é descrever o desenho, os métodos e as características amostrais da Avaliação Multidimensional e Tratamento da Ansiedade em Crianças e Adolescentes - Projeto PROTAIA. Método: Escolares entre 10 e 17 anos de todas as escolas pertencentes à área de abrangência da unidade de atenção primária do Hospital de Clínicas de Porto Alegre foram incluídos no projeto. O projeto compreende cinco fases: 1) triagem comunitária; 2) diagnóstico psiquiátrico; 3) avaliação multidimensional, incluindo fatores ambientais, neuropsicológicos, nutricionais e marcadores biológicos; 4) tratamento; e 5) fase translacional. Resultados: Um total de 2.457 sujeitos foram triados para transtornos de ansiedade na comunidade. Dos indivíduos que compareceram à avaliação diagnóstica, 138 foram detectados com ao menos um transtorno de ansiedade (excluindo fobia específica) e 102 indivíduos sem nenhum transtorno de ansiedade. Dentre os casos de ansiedade, o transtorno de ansiedade generalizada ( $\mathrm{n}=95 ; 68,8 \%$ ), transtorno de ansiedade social ( $\mathrm{n}$ $=57 ; 41,3 \%)$ e o transtorno de ansiedade de separação $(\mathrm{n}=49 ; 35,5 \%)$ foram os mais frequentes. Conclusáo: O projeto PROTAIA é um projeto de pesquisa promissor que pode contribuir para o entendimento da relação entre transtornos de ansiedade e fenótipos relacionados à ansiedade com vários fatores de risco, tanto genéticos quanto ambientais.

Descritores: Ansiedade; Transtornos fóbicos; Pânico; Epidemiologia; Comorbidade
Submitted: December 6, 2010

Accepted: February 27, 2011

\author{
Correspondence \\ Gisele Gus Manfro \\ Hospital de Clínicas de Porto Alegre \\ R. Ramiro Barcelos, 2350 - room 2202 \\ 90035-003 Porto Alegre, RS, Brazil \\ Phone/Fax: (+55 51) 3359-8983 \\ Email:gmanfro@gmail.com
}

181 Revista Brasileira de Psiquiatria $\bullet$ vol $33 \cdot n^{\circ} 2 \cdot$ jun2011 


\section{Introduction}

Cross-sectional studies have shown that anxiety disorders are the most prevalent psychiatric disorders, ${ }^{1,2}$ with lifetime inter-quartile range prevalence rates of 9.9 to $16.7 \%$ worldwide. ${ }^{1}$ Childhood and adolescence are the principal risk phases for the development of anxiety symptoms ${ }^{3}$ with $75 \%$ of all anxiety disorders having their onset before the age of 21 and about $50 \%$ before age 11 . Prospective studies have also shown that $55 \%$ of those with a diagnosis of anxiety disorder in adulthood have already had a positive diagnostic assessment at 11 to 15 years of age. ${ }^{4}$

Different endophenotypes, ${ }^{5}$ such as behavioral inhibition, neuroticism, anxiety sensitivity, introversion and harm avoidance have been associated with the complexity of anxiety-proneness. Although anxiety can be expressed as a continuum, the Diagnostic and Statistical Manual of Mental Disorders - fourth revised edition (DSM-IV-TR) ${ }^{6}$ clinically categorises the following disorders: separation anxiety disorder (SeAD), specific phobias (SP), social anxiety disorder (SoAD), agoraphobia $(A G)$, panic disorder (PD), generalized anxiety disorder (GAD). Obsessive-compulsive disorder and post-traumatic stress disorder are also classified in the anxiety disorders group, according to the current version of the DSM-IV-TR, however, their grouping with the other anxiety disorders is controversial. ${ }^{7-9}$

The continuous nature of anxiety impairs the longitudinal study of these disorders. Some authors have pointed out that a diagnosis of an anxiety disorder has low stability across the lifespan, with a considerable degree of fluctuation in diagnostic status and a strong tendency to naturally wax and wane over time, particularly among younger groups. ${ }^{10}$ Despite this, longitudinal studies have demonstrated that a few anxious children and adolescents enter adulthood without any diagnosis. For instance, only $13 \%$ of baseline SoAD cases in the Early Developmental Stages of Psychopathology were free of any diagnosis during the 10-year follow-up; 35\% reported the same disorder and 64\% reported the presence of another anxiety disorder or depression. ${ }^{11}$ It seems that there is a heterotypic continuity across time or a sequential comorbid pattern. ${ }^{12,13}$

These fluctuating patterns across the lifespan are best understood from a developmental perspective. Genes and environmental factors have several ways to interplay in order to change neural substrate, human behaviors and emotions. A variety of developmental progressions can arise from the same set of risk and protective factors which may result either in a particular disorder (equifinality), or differing outcomes (multifinality). ${ }^{14}$ These influences can be observed even later in life. ${ }^{15}$

Taking this into consideration, a challenging task is to establish specific risk factors for anxiety disorders. Low socioeconomic status, poor parenting style, parental psychopathology, childhood maltreatment, and life events ${ }^{3}$ have already been implicated in the development of anxiety disorders. However, the complex relationship between these risk factors, genetic factors and phenotypic presentations is poorly understood. In addition, few studies have evaluated other factors intimately related to anxiety, such as diet, food intake and their consequences ${ }^{16}$ or investigated evidence-based cognitive behavioral manuals for treating anxiety disorders in low and middle income countries (LMIC).

The objective of this article is to briefly describe the multistage design, the methods and to present preliminary findings of the Multidimensional Evaluation and Treatment of Anxiety in Children and Adolescents - the PROTAIA Project.

\section{Method}

The PROTAIA (Anxiety Disorders Program for Child and Adolescent Psychiatry) is an emerging program at the Hospital de Clinicas de Porto Alegre - Universidade Federal do Rio Grande do Sul (HCPA-UFRGS) that aims to study anxiety disorders using a comprehensive, research-based perspective to conduct a multidisciplinary project. In this collaborative project there are many hypotheses established on an a priori basis being tested under several theoretical approaches. It has an exploratory nature in order to generate hypotheses to be confirmed in larger samples. This prolific new working group comprises psychiatrists, child and adolescent psychiatrists, pediatricians, speech therapists, nurses, therapists, psychologists, molecular biologists, experimental researchers and nutritionists.

\section{Phases of the PROTAIA Project}

The starting point of the PROTAIA Project is the Community Screening Phase, in which all children and adolescents between 10 and 17 years of age from the six schools belonging to the Primary Care Unit of HCPA catchment area were invited to participate. A screening scale for anxiety disorders (Screen for Child and Anxiety Related Emotional Disorders - SCARED) and other instruments were administered to all students that agreed to participate. The cross-sectional design as a starting point for this study has three main objectives: (1) to screen for anxiety disorders in the community; (2) to provide data for validation of clinical scales and normative scores; and (3) to identify subjects with high probability of having anxiety disorders and a community control group from the same population for subsequent projects.

The second step, directly related to the Community Screening Phase, is the Diagnostic Phase. In this phase all subjects above the $75^{\text {th }}$ percentile in the screening scale (SCARED) ${ }^{17,18}$ and their parents were invited to undergo a diagnostic clinical interview and a structured clinical interview (K-SADS-PL) with psychiatrists, based on a DSM-IV structured interview. Additionally, a random sample of controls equally distributed in the other three quartiles of the SCARED was invited to participate in the psychiatric evaluation. The two main objectives of this step are: (1) to estimate prevalence rates of anxiety disorders in the regional population and (2) to define a community sample of cases with anxiety and a control sample of subjects without anxiety from the same population.

The third step, also associated with the previous steps, is the Multidimensional Evaluations Phase. In this phase, nutritional, obstetric and pediatric history was assessed and metabolic 
and neuropsychological tests were performed. Moreover, we evaluated genetics from family trios, environmental measures associated with stress (e.g., bullying, peer victimization, parental bonding, childhood trauma, family functioning, etc), parental psychopathology, endophenotypic measures from children, adolescents and their parents, as well as measures of quality of life. This assessment was performed in sub-samples in order to allow exploratory analysis and to study different hypotheses defined $a$ priori based on the literature. The main objective of this phase is to provide a large dataset of measures in order to better understand the complexity of and the relationship between anxiety symptoms and disorders with genetic and environmental factors.

The fourth step is the Treatment Phase. Since there is no validated protocol to treat young patients with anxiety disorders in Brazil, a group of therapists with large experience in Cognitive Behavior Group Therapy (CBGT) developed a manual of CBGT based on the most used foreign manuals to date. ${ }^{19-21}$ The main objective of this phase is to develop a new manual, based on the previous ones, in order to treat internalizing disorders in-group as an alternative approach to public health strategies in Psychiatry.

The fifth step is the Translational Phase. PROTAIA also serves as a base for the development of translational models in experimental animal research, aiming to clarify the possible mechanisms involved in the human findings.

\section{Training}

1) Community phase training

The community phase was carried out in three stages: (1) June 2008 (for the biggest school included); (2) November 2008 (for the second biggest school included) and (3) April 2009 for the remaining schools. The community study was performed in three different stages in order to provide an optimal time between screening evaluation and diagnostic assessment.

Twelve research assistants were trained over two days to administer the research protocol to 10 to 17 year old children and adolescents. Training involved instructions regarding "what to do" and "what to answer" during school-administered self-rated protocols and to assess accurate information about truancy, school transfer and school dropout with the teachers and directors. Training also involved a pilot study in a non-participant school with 85 students.

2) Diagnostic evaluation training and inter-rater reliability

Diagnostic assessment was performed between August 2008 and December 2009, by Psychiatry residents $(n=4)$, psychiatrists $(n=1)$ and child and adolescent psychiatrists $(n=4)$ under the supervision of a senior psychiatrist (GGM). All interviewers had undergone a K-SADS-PL training process for one month that consisted of four phases: (1) 4 seminars of 2 hours each about the structure and diagnostic criteria of the instrument, conducted by two child and adolescent psychiatrists (AGT and LRI) and a highly trained researcher with an experience of more than 100 K-SADSPL interviews (CK); (2) observation of 5 K-SADS-PL interviews, in vivo, performed by a senior interviewer; (3) administration of the K-SADS-PL in 2 patients by the trainees under the supervision of a trained interviewer; (4) pair by pair factorial combination of each interviewer (i.e., at least two interviews with every interviewer). Decisions over final diagnoses were reached in a clinical committee (whenever necessary), conducted by child and adolescent psychiatrists with clinical experience (LRI and AGT) and a senior psychiatrist (GGM).

Inter-rater reliability was achieved by watching and rating 16 DVD K-SADS-PL interviews with child and adolescent patients and healthy controls. Inter-rater reliability resulted in a kappavalue of 0.932 for the anxiety disorders module. Regarding the presence of a specific anxiety disorder, the research assistants reached a kappa value of 1.00 for $\mathrm{PD}, \mathrm{GAD}$ and SeAD; a kappa value of 0.917 for SoAD and 0.873 for SP.

The subjects were invited to undergo clinical evaluation by phone. A loss of contact was defined after 5 calls over 5 different days, at different times of day.

3) Nutritional and body composition evaluation

All researchers involved in the evaluation of nutritional and body composition were trained for 40 hours in the study of anthropometric techniques and bioelectrical impedance analysis (BIA), the study of the tools to collect and record data and the study of the ethical aspects of research. Afterwards, trainees were shown how to handle the calibration of the scale, stadiometer, calipers, BIA and software analysis of macro and micronutrients; they followed this by training the nutritional measurements and procedures to a pilot group of children and adolescents.

\section{Clinical evaluations and rating scales in the PROTAIA Project}

In order to elicit new research collaboration, we decided to publish the research protocol used in this project.

1) Psychiatric scales

Both validated and non-validated scales were used in the PROTAIA protocol. Since there are few validated instruments in child and adolescent Psychiatry, non-validated scales were subjected to a process of transcultural adaptation that consisted of two translations followed by the evaluation of the revised translated version by a group of experts and focus groups. One of the objectives of the PROTAIA project is to validate psychiatric scales. Tables 1 and 2 provide an overview of the psychiatric scales used in the community and diagnostic phases.

In the community phase, the self-rated instruments were administered in school classes with careful supervision of the research assistants. Random scales were administered using a systematically random process involving an " $S$ " distribution of questionnaires (in order to avoid bias related to the seating places in the classroom), in a ratio of 1 questionnaire per 6 students in the June/2008 data collection and 1 questionnaire per 5 in the August/2008 and April/2009 data collections. In the multidimensional evaluation phase, the self-rated instruments were delivered in manila envelopes after the diagnostic assessment and were collected at the school.

a) The Screening Scale

The SCARED scale is a 41 -item broad screening instrument

183・Revista Brasileira de Psiquiatria • vol $33 \bullet \mathrm{n}^{\circ} 2 \cdot$ jun2011 
Table 1 - Self-rated Instruments used in the community phase by scholars

\begin{tabular}{|c|c|c|c|}
\hline Community phase & Participants & $\begin{array}{l}\text { Validated in } \\
\text { Brazil }\end{array}$ & Construct \\
\hline 1. Sociodemographic questionnaire & All & Yes & Socio-demographic \\
\hline $\begin{array}{l}\text { 2. Screen for Children and Adolescent } \\
\text { Emotional Related Disorders - Child } \\
\text { version (SCARED-C) }{ }^{17,18}\end{array}$ & All $(n=2457)$ & $\mathrm{No}^{*}$ & Anxiety symptoms according to DSM-IV \\
\hline 3. Olweus questions to assess Bullying ${ }^{45,46}$ & All $(n=2476)$ & $\mathrm{No}^{*}$ & Bullying in general \\
\hline $\begin{array}{l}\text { 4. Strengths and Difficulties Questionnaire } \\
(\text { SDQ })^{47,48}\end{array}$ & Random $(n=475)$ & $\mathrm{Yes}^{33}$ & $\begin{array}{l}\text { Difficulties related to emotional problems, conduct } \\
\text { problems, hyperactivity/inattention, peer relationship } \\
\text { problems and prosocial behavior }\end{array}$ \\
\hline $\begin{array}{l}\text { 5. Multidimensional Anxiety Scale for } \\
\text { Children (MASC) }\end{array}$ & Random $(n=459)$ & $\mathrm{No}^{* *}$ & $\begin{array}{l}\text { Anxiety according with some constructs of DSM-IV and } \\
\text { alternative phenotypes }\end{array}$ \\
\hline 6. Childhood Depression Inventory $(\mathrm{CDI})^{50}$ & Random $(n=454)$ & $Y \mathrm{~s}^{51-53}$ & Depression according to DSM-IV and Suicide Ideation \\
\hline 7. Youth Quality of Life (YQOL) $)^{54,55}$ & Random $(n=419)$ & $\mathrm{No}^{* *}$ & Quality of life in children and adolescents \\
\hline $\begin{array}{l}\text { 8. Childhood Anxiety Sensitivity Index } \\
(\text { CASI })^{55 \dagger}\end{array}$ & Random $(n=158))$ & No* & Anxiety Sensitivity \\
\hline $\begin{array}{l}\text { 9. Peer Interaction for the Primary School } \\
\text { (PIPS) }^{57 t}\end{array}$ & Random ( $\mathrm{n}=157)$ & No* & School Bullying \\
\hline $\begin{array}{l}\text { 10. Behavioral Inhibition Instrument } \\
(\mathrm{BII})^{58+t}\end{array}$ & Random $(n=869)$ & $\mathrm{No}^{*}$ & Behavioral Inhibition for children \\
\hline $\begin{array}{l}\text { 11. Retrospective Self-report of Inhibition } \\
\text { (RSRI) }^{59}-\text { adapted for children and } \\
\text { adolescents }\end{array}$ & Random $(n=454)$ & $\mathrm{No}^{* * *}$ & $\begin{array}{l}\text { Behavioral Inhibition for adults adapted in order to } \\
\text { measure current inhibition in the scholars }\end{array}$ \\
\hline 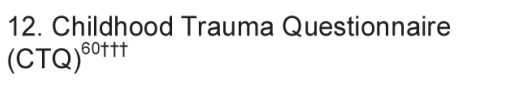 & Random $(n=307)$ & $Y_{e s}{ }^{61}$ & $\begin{array}{l}\text { Traumatic experiences in a retrospective basis (abuse } \\
\text { and neglect - emotional, physical and sexual) }\end{array}$ \\
\hline 13. Resilience Scale (RES) ${ }^{62 \ddagger}$ & Random $(n=244)$ & Yes $^{63}$ & Resilience construct \\
\hline $\begin{array}{l}\text { 14. Alcohol, Smoking and Substance } \\
\text { Involvement Screening Test (ASSIST) }\end{array}$ & Random $(n=235)$ & Yes $^{65}$ & Screening test for alcohol, smoking and substance use \\
\hline
\end{tabular}

Validation information: * Cross-cultural adaptation for the purposes of PROTAIA project; ** Scales with complete translational process, but without validation studies in the country; ${ }^{* * *}$ Scales adapted from adults to children and adolescents.

Note: ${ }^{\dagger}$ Only used in April 2009 data collection (systematically random in 1 from each 5 students); ${ }^{+\dagger}$ Only used in April 2009 data collection (for all students); ${ }^{+t}$ Only used in August 2008 (systematically random in 1 from each 5 students) and April 2009 data collection (systematically random in 1 from each 5 students); ${ }^{7}$ Only used in June 2008 (systematically random in 1 from each 6 students) and August 2008 data collection (systematically random in 1 from each 5 students); ${ }^{\ddagger}$ Only used in June 2008 data collection (systematically random in 1 from each 6 students).

which offers a self- and a parent-report version. ${ }^{17,18}$ This instrument has four subscales that were developed on the basis of the DSM-IV classification of anxiety disorders (panic disorder, generalized anxiety disorder, separation anxiety disorder and social anxiety disorder) and a fifth subscale (school anxiety) that represents a common anxiety problem in children and adolescents. A recent meta-analysis evaluating the cross-cultural psychometrics of SCARED suggested that this scale has robust psychometric properties demonstrating good internal consistency, test-retest reliability, parentchild correlation, convergent and discriminant validity. ${ }^{22}$

2) Nutritional evaluation

Anthropometric measurements were performed in duplicate and taken by using standard techniques and calibrated equipment. ${ }^{23}$ Body weight was measured with portable digital electronic balance scales $\left(\right.$ Marte $\left.^{\circledast}\right)$, (Marte, SR Sapucaí, MG, Brazil), and height with an extensible portable stadiometer (Alturexata, BH, MG, Brazil). Arm circumference and waist circumference were measured with a tape measure (Sanny, SBC, SP, Brazil). ${ }^{24,25}$ The subscapular and triceps skinfolds were measured using a caliper (Cescorf, Porto Alegre, RS, Brazil). ${ }^{26}$ The sexual maturation stage was determined by a self-assessment, according to Tanner's criteria. ${ }^{27}$
The assessment of the body composition was measured by bioelectrical impedance analysis (BIA) (Biodynamics-450, Seattle, WA, EUA). ${ }^{28}$ Physical activity was assessed based on 3-day physical activity records (PAR24h) ${ }^{29}$ The levels of regular physical activity were determined by means of a self-report instrument which provided an estimate of energy expenditure and time spent in different activities.

Food intake estimates were made using 24-h food records and by a food frequency questionnaire for adolescents (AFFQ), ${ }^{30,31}$ with the aid of a food and utensils photo album. The quantitative analysis of macro- and micronutrients consumed was calculated with the use of NutriBase ${ }^{\circledR}$ software (Version NB7 Network) (Phoenix, AZ, USD).

\section{3) Neuropsychological evaluation}

In addition to the above assessments, a sub-sample of cases and controls were evaluated through neuropsychological tests. The neuropsychological battery is presented in Table 4 and was performed in three 40-minute weekly sessions at school. Sixtyeight children were assessed ( 41 with a current anxiety diagnosis and 27 controls without current anxiety diagnosis). Cases and controls did not differ regarding age or gender (data not shown). 
Table 2 - Instruments used in the diagnostic phase and multidimensional evaluation phase

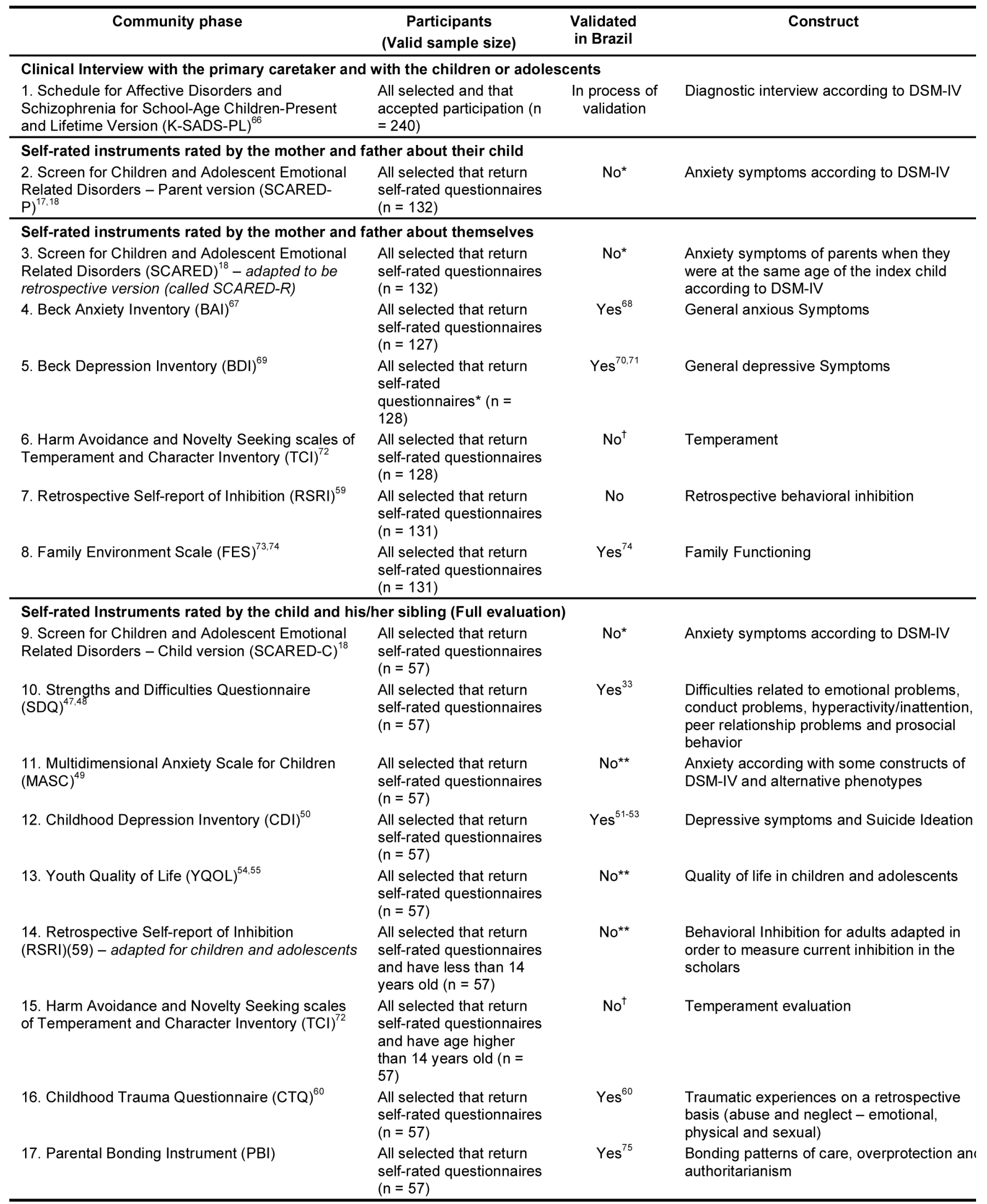

Validation information: * Cross-cultural adaptation for the purposes of PROTAIA project: ** Scales with complete translational process, bu without validation studies; ${ }^{* * *}$ Scales adapted from adults to children and adolescents; ${ }^{+}$Only the TCI-revised version is validated in Brazil, ${ }^{76}$ bu this version was not available at the time of protocol elaboration and data collection in 2007/2008 and therefore another version with som previous investigation in anxiety disorders was used. ${ }^{77}$ Note: The sibling with the least age difference related to the index child.

$185 \cdot$ Revista Brasileira de Psiquiatria $\bullet$ vol $33 \cdot n^{\circ} 2 \cdot$ jun2011 
Table 3 - Nutritional, body composition and metabolic evaluation

\begin{tabular}{|c|c|c|c|}
\hline Instrument & Participants & $\begin{array}{l}\text { Validated in } \\
\text { Brazil }\end{array}$ & Construct \\
\hline $\begin{array}{l}\text { 1. The 24-hour food records } \\
(\text { FR24h) }\end{array}$ & $\begin{array}{l}\text { Participants of Nutritional and } \\
\text { Body Composition evaluation }\end{array}$ & $\mathrm{N} / \mathrm{A}$ & $\begin{array}{l}\text { Food intake of the Macronutrients and micronutrients / } \\
\text { feeding behavior }\end{array}$ \\
\hline $\begin{array}{l}\text { 2. Food frequency } \\
\text { questionnaire for adolescents } \\
\text { (AFFQ) }^{1}\end{array}$ & & $\mathrm{Yes}^{63}$ & $\begin{array}{l}\text { Food intake of the Macronutrients and micronutrients / } \\
\text { feeding behavior }\end{array}$ \\
\hline $\begin{array}{l}\text { 3. 3-day physical activity } \\
\text { record (PAR24h) }{ }^{2}\end{array}$ & & $Y_{e s}{ }^{63}$ & Physical activity \\
\hline $\begin{array}{l}\text { 4. Self-assessment of sexual } \\
\text { maturation stage }{ }^{4}\end{array}$ & & $Y_{e s}{ }^{63}$ & Sexual maturation \\
\hline $\begin{array}{l}\text { 5. Anthropometric } \\
\text { assessment and bioelectrical } \\
\text { impedance analysis }(\mathrm{BIA})^{28}\end{array}$ & & $\mathrm{~N} / \mathrm{A}$ & $\begin{array}{l}\text { Weight }(\mathrm{W}) \text {, stature (S), arm circumference (AC), waist } \\
\text { circumference (WC), tricipital skinfolds (TSF), } \\
\text { subscapular skinfolds (SSF) and bioelectrical } \\
\text { impedance analysis (BIA) }\end{array}$ \\
\hline 6. Biochemical indicators ${ }^{9}$ & $\begin{array}{l}\text { All selected that accepted } \\
\text { participation with collection of } \\
\text { biological material through } \\
\text { blood samples }\end{array}$ & $N / A$ & $\begin{array}{l}\text { Glycemia, total cholesterol, high-density lipoproteins } \\
\text { (HDL } \neg c) \text {, low-density lipoprotein (LDLC), triglycerides } \\
\text { (TG), thyroid stimulating hormone (TSH), hormones } \\
\text { insulin, and Homeostasis Model Assessment (HOMA) }\end{array}$ \\
\hline
\end{tabular}

N/A, Not applicable

4) DNA extraction and genotyping

DNA was extracted from saliva using the Oragene ${ }^{\circledR}$ DNA Selfcollection kit (DNA Genotek) according to the manufacturer's instructions. The biological sample was collected from the participants and their parents. When one of the parents was unavailable, the biological sibling with the least age difference available at the time was invited to participate in the study. The DNA samples were stored at $-4^{\circ} \mathrm{C}$ and the amplification of the region of interest was performed by Polymerase Chain Reaction (PCR), using reported primers, followed by digestion with specific restriction enzymes (RFLP). The digested products were submitted to $3 \%$ agarose gel electrophoresis and visualized with ethidium bromide staining under UV light.

5) Blood sample collection and storage

Blood collection was performed in the outpatient research clinic of the HCPA. The adolescents arrived at the center in the morning (between 7 and $10 \mathrm{am}$ ) accompanied by the legal guardian, having fasted for 10 to 12 hours. Three tubes containing $4.5 \mathrm{ml}$ of blood samples were obtained by venipuncture and transported immediately in ice boxes to the Clinical Pathology laboratory for analysis of glucose, TSH, total cholesterol, HDL, triglycerides and insulin. Two other samples were stored for future molecular and hormonal studies: total blood in EDTA tubes, stored at -20C, and serum (separated from the other blood components after centrifugation for 5 minutes at $4.500 \mathrm{rpm}$ ) stored at $-80 \mathrm{C}$ in the Protein and Molecular Analysis Laboratory.

\section{Cognitive behavior therapy protocol development}

Four therapists (two clinical psychologists and two psychiatrists) supervised by researchers with a minimum of 10 years' experience in CBT developed a treatment protocol for children and adolescents with anxiety disorders based on the Coping Cat - Workbook (19, 20), FRIENDS Programme ${ }^{21}$ and personal experience, taking into consideration particular cultural issues.

Table 4 - Neuropsychological tests

\begin{tabular}{|c|c|c|}
\hline Dimensions & Participants & Neuropsychologic tests \\
\hline 1. Intelligence & Selected case-controls & Wechsler Abbreviate Scale of Intelligence-WASI ${ }^{* 78}$ \\
\hline 2. Working memory & Selected case-controls & Digit Verbal Span ${ }^{79}$ \\
\hline 3. Attention & Selected case-controls & $\begin{array}{l}\text { Trail Making Test }-A \text { and } B^{80} \\
\text { D2 }{ }^{81} \\
\text { Go-No-Go test }{ }^{82}\end{array}$ \\
\hline 3. Mental flexibility & Selected case-controls & Wisconsin Card Sorting Task (WCST) ${ }^{.83}$ \\
\hline 4. Memory and planning & Selected case-controls & $\begin{array}{l}\text { WMS-R - Wechsler Memory Scale - Revised - Logic memory }{ }^{79} \\
\text { The Rey Complex Figure } \\
\text { RAVLT - Rey Auditory Verbal Learning Test }{ }^{85}\end{array}$ \\
\hline 5. Emotional processing & Selected case-controls & Labeling Pictures of Facial Affection (POFA) / Ekman ${ }^{86}$ \\
\hline
\end{tabular}


Due to the different developmental characteristics of individuals between 10 to 17 years, the treatment was stratified into two age groups: children from 10 to 13 years, and adolescents from 14 to 17 years. The final CBT protocol was tested in a pilot group and was administered in group format (6 to 10 patients per group), limited to 1490 -minute sessions (10 to 13 years) and 1290 -minute sessions (14 to 17 years), over 4 months. In brief, the four main elements of CBT were: (1) the recognition and description of the physical symptoms of anxiety, (2) the recognition and modification of thoughts that contribute to their anxious experiences (negative self-talk), (3) the development of a plan (confrontation strategies) to deal with the situations which cause anxiety, and (4) performance evaluation and the choice of self-reward. Although the treatment was focused on the child or adolescent, two psychoeducational sessions (one in the middle and another at the end) with parents were included.

\section{Data entry}

Double entry of the data was performed item-by-item generating more than 3,000 core variables. Paper questionnaires were checked if discrepancies between the two entries were found. In general, replacement of missing values with the linear trend of a point were allowed if missing values item by item did not represent more than $20 \%$ of the whole scale.

\section{Ethical considerations}

This study was approved by the ethical committee of Hospital de Clinicas de Porto Alegre (number 08-017). In the initial community phase we used dissent forms. For the subsequent phases, separate written informed consents from primary caretakers and children and adolescents were collected.

\section{Results}

From the six public schools in the primary care system area, encompassing 2,754 students, 2,537 were covered by the survey (92.1\%), 2,325 (91.6\%) by the first visit at the school and 212 $(8.4 \%)$ at rescue days for the initially missing students. From these 2,537 students, 80 (3.2\%) refused to participate. From this sample, 842 subjects were selected for further clinical evaluation and 160 (26.6\%) and $80(33.3 \%)$ from the positive and negative screening groups respectively attended the diagnostic evaluation interview. A biological sample for DNA analysis was collected from 242 children. Figure 1 describes the flow diagram of subjects enrolled.

The sample that attended school screening was fairly similar to the one that refused to participate, with the exception of a higher proportion being female $(\mathrm{OR}=1.6 ; \mathrm{p}=0.049)$ and younger [12.8 years $(S D=2.37)$ vs. 14.0 years $(S D=2.51) ; \mathrm{p}<0.001]$. The sample that attended school screening but not diagnostic assessment was also similar, with no difference regarding gender $(\mathrm{OR}=0.79 ; \mathrm{p}=0.151)$, but with a higher chance of being older [12.8 $(\mathrm{SD}=2.38)$ vs. $13.9(\mathrm{SD}=2.51) ;(\mathrm{p}<0.001)]$. There were no other significant differences regarding symptoms or risk factors.
Clinical characteristics of the sample that attended diagnostic assessment are depicted in Table 5.

The epidemiological design was intended to adjust for complex samples adjusting for oversampling in the upper quartile. However, unfortunately, males were less likely to attend the diagnostic evaluation than females. Out of those selected for diagnostic evaluation, $60 \%, 44 \%, 18 \%$ and $16 \%$ of males and $75 \%, 73 \%$, $48 \%$, and $20 \%$ of females, in each quartile respectively, attended the diagnostic evaluation. Therefore, the male:female ratio regarding selection in and attendance of the diagnostic phase became unbalanced in each of the quartiles not favoring the weighting in the cross-sectional oversampling design.

On the other hand, the selection based on the $75^{\text {th }}$ percentile of the screening scale increased the number of anxious cases in our sample between 3 and 8 times as compared to the sample below the arbitrary threshold, allowing comparisons between cases and controls selected from this community sample. Between those with a positive lifetime diagnosis for anxiety disorders 95 (68.8\%) had GAD, 57 (41.3\%) had SoAD, 49 (35.5\%) had SeAD and 9 (6.5\%) had PD.

A sub-analysis undertaken only by the psychiatrists blinded to the screening results in randomly selected subjects equally distributed into the four quartiles of SCARED, revealed that SCARED has good predictive characteristics of lifetime anxiety diagnosis as a group as compared to psychiatric diagnosis using K-SADS-PL (area under the curve $=0.739$; CI95\% 0.651-0.826; $\mathrm{p}<0.001 ; \mathrm{n}=119)$. However, the $75^{\text {th }}$ percentile has demonstrated low sensitivity (50\%) and high specificity (81\%) for case detection and, therefore, it is possible that severe cases of anxiety disorder are over-represented in this sample.

Although we have demonstrated high rates of comorbidity between anxiety diagnoses, out of the 15 possible presence/ absence combinations between SeAD, GAD, SoAD and PD in patients with at least one anxiety disorder, the diagnosis of GAD was the most frequent condition $(30.4 \% ; n=42)$, followed by SoAD $(14.5 \% ; n=20)$ and SeAD $(12.3 \%$; $n$ = 17) without any other anxiety disorder comorbidity. PD was the only anxiety disorder diagnosis more common in comorbidity with other anxiety disorders $(3.5 \% ; \mathrm{n}=5)$ than without comorbidity $(2.2 \% ; \mathrm{n}=3)$ in our sample. Regarding comorbid combinations, GAD with SoAD had the highest rate $(15.2 \% ; n=21)$ followed by SeAD and GAD (10.9\%; $n$ $=15)$, and the comorbidity between these three conditions, SoAD, SeAD and GAD $(8.7 \% ; \mathrm{n}=12)$. Further combinations did not reach more than $2 \%$ of the total sample. These results can be seen in Figure 2.

There were no associations between having at least one anxiety disorder with non-anxious psychiatric comorbidities considering the negative screening sample (all p-value $>0.05$ ), except for specific phobia $(\mathrm{OR}=3.68$; CI95\% 1.37-9.92; $\mathrm{p}=0.012)$. On the other hand, there was an association between having at least one anxiety disorder and major depression $(\mathrm{OR}=3.23$; CI95\% 1.17-8.91; $\mathrm{p}=0.022$ ) and between having at least one anxiety disorder and specific phobia $(\mathrm{OR}=7.45$; CI95\% 2.75-20.22; $\mathrm{p}<$

$187 \cdot$ Revista Brasileira de Psiquiatria $・$ vol $33 \cdot n^{\circ} 2 \cdot$ jun2011 


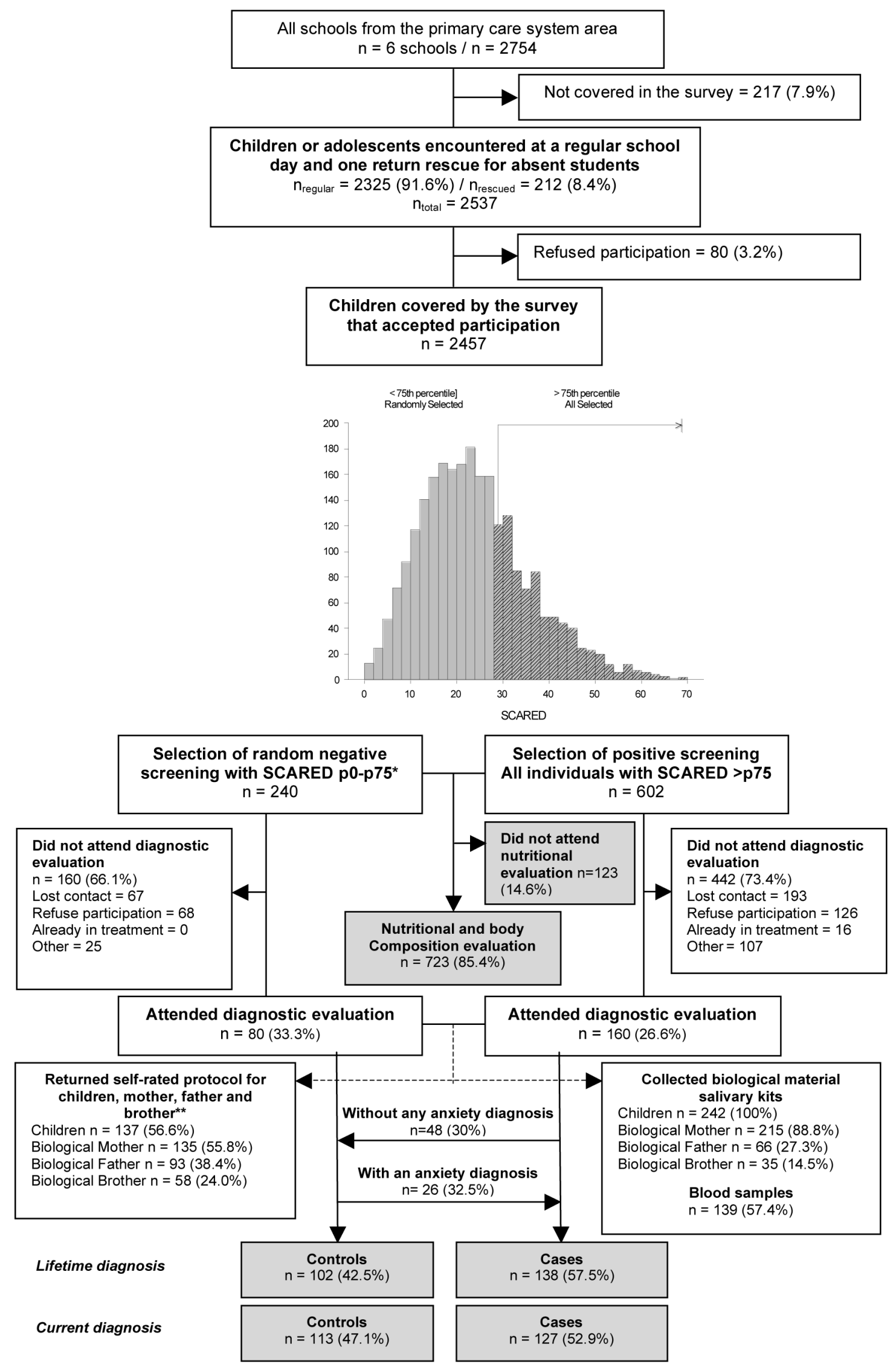

Figure 1 - Flow diagram of subjects enrolled. 


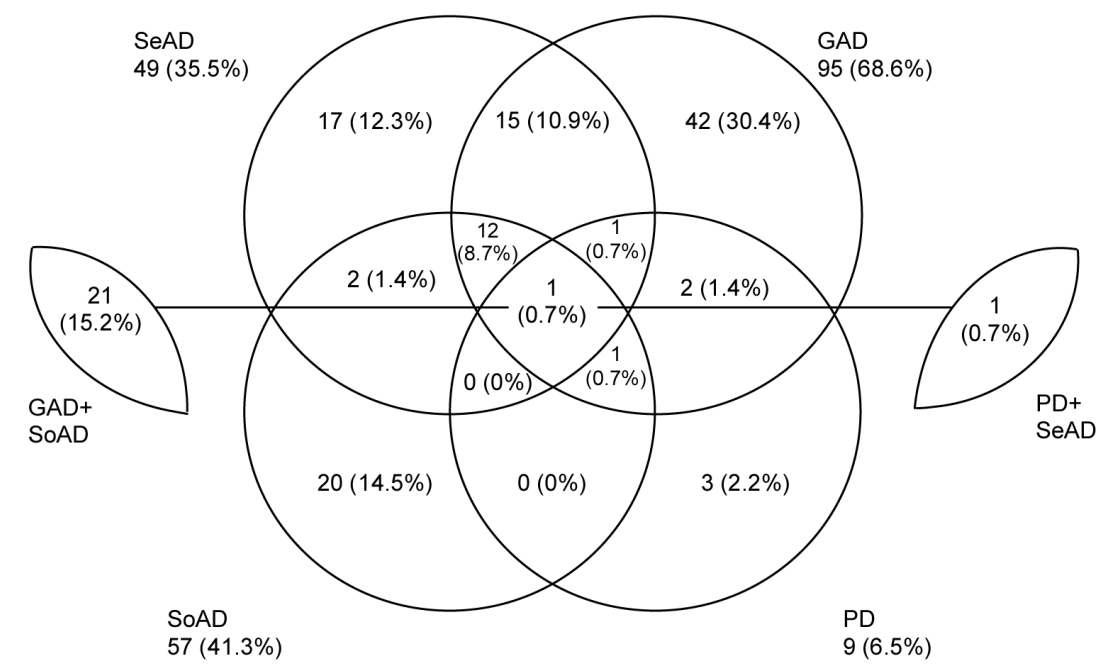

Figure 2 - Anxiety comorbidity between anxious cases.

Obs.: $n$ (\%) inside circles represent prevalence rates within anxious individuals. Number (\%) inside intersections represent prevalence rates within anxious individuals with comorbid disorders between the conditions of the given circle. There are 15 combinations possible between So $A D$, SeAD, $P D$ and $G A D$.

0.001) among those from the positive screening sample. Gender, age and socio-economic status did not differ between anxious and non-anxious groups (all p-values $>0.05$ ) in both positive and randomly negative screening samples. These results are depicted in Table 5 .

\section{Discussion}

The PROTAIA Project is an example of a planned multidisciplinary project with different dimensional types of assessment. It involves several types of evaluation with a careful methodological approach, through which we were able to identify 138 cases of anxiety disorders. This report aims to describe our research protocol and the preliminary results.

We were able to successfully increase the number of anxious cases in our sample with the use of the $75^{\text {th }}$ percentile of the SCARED oversampling procedure. However, since ROC analysis reveal a low sensitivity, it is possible that severe cases are over-represented. Another study that used a similar selection procedure selecting the top $15 \%$ most anxious (high anxious) on SCARED and \pm 2 points on SCARED from the median score (median anxious) was also able to increase the number of anxious cases using this screening method. ${ }^{32}$

The most common anxiety disorder found in our sample was GAD, followed by SoAD and SeAD. In one epidemiological study restricted to school children between 7 and 14 years old in one southeast Brazilian city, not otherwise specified anxiety was the most prevalent disorder (2.1\%) followed by SeAD (1.4\%), SoAD $(0.7 \%)$ and GAD $(0.4 \%) .{ }^{33}$ In addition, in another well- designed epidemiological study of adolescents (13 to 18 year old children), higher prevalences of SoAD (9.1\%) and SeAD (7.6\%) were found compared to GAD (2.2\%). ${ }^{34}$ Studies that used similar designs using SCARED as a screening method also find SoAD and SeAD (prevalence rates within high anxious individuals: $21 \%$ and $16 \%$, respectively) to be more prevalent than GAD (15\%). ${ }^{32}$ We believe that differences in frequency rates between these diagnoses can be attributed to different diagnostic instruments, differences in attendance of diagnostic interviews (the lower rates of attendance in our study can decrease the prevalence of disorders with a higher phobic and avoidant component such as SoAD and SeAD). Additionally, we cannot rule out that these differences are not due to SCARED.

Like other studies, ${ }^{33}$ our results demonstrated an association between anxiety disorders and major depression once these two conditions consistently are classified as internalizing disorders. ${ }^{35}$ We observed neither an association between ODD and CD, as indicated by some studies ${ }^{33}$ nor between anxiety and ADHD. ${ }^{36}$ The comorbidity patterns regarding internalizing and externalizing disorders are still controversial in epidemiological studies. This may be due to differences between shared and non-shared genetic and environmental risk factors as well as differences in the diagnostic process used. Moreover, the oversampling procedure and differential sex attendance to the diagnostic evaluation in our study may be responsible for our findings.

Furthermore, our sample is composed of a high number of cases of ADHD ( $\mathrm{n}=63)$ and ODD $(\mathrm{n}=38)$ in both positive and randomly selected negative screening. Assuming an independent

$189 \cdot$ Revista Brasileira de Psiquiatria $・$ vol $33 \cdot n^{\circ} 2 \cdot$ jun2011 
Table 5 - Descriptive characteristics of the sample who attended diagnostic assessment stratified by screening scale and anxiety diagnosis

\begin{tabular}{|c|c|c|c|c|c|c|c|c|}
\hline & \multirow{2}{*}{\multicolumn{4}{|c|}{$\begin{array}{c}\text { Randomly selected from negative screening } \\
\text { Any anxiety disorder }(n=80)\end{array}$}} & \multicolumn{4}{|c|}{ Positive screening } \\
\hline & & & & & & ny anxiet & er $(n=1$ & \\
\hline & \multicolumn{2}{|c|}{$\begin{array}{l}\text { Absent } \\
(n=54)\end{array}$} & \multicolumn{2}{|c|}{$\begin{array}{l}\text { Present } \\
(n=26)\end{array}$} & \multicolumn{2}{|c|}{$\begin{array}{l}\text { Absent } \\
(n=48)\end{array}$} & \multicolumn{2}{|c|}{$\begin{array}{l}\text { Present } \\
(\mathrm{n}=112)\end{array}$} \\
\hline & $\mathbf{n}$ & $\%$ & $\mathbf{n}$ & $\%$ & $\mathbf{n}$ & $\%$ & $\mathrm{n}$ & $\%$ \\
\hline \multicolumn{9}{|l|}{$\begin{array}{l}\text { Socio-demographic } \\
\text { variables }\end{array}$} \\
\hline Gender (female) & 30 & $55.6 \%$ & 19 & $73.1 \%$ & 32 & $66.7 \%$ & 83 & $74.1 \%$ \\
\hline White skin color* & 45 & $83.3 \%$ & 20 & $76.9 \%$ & 28 & $59.6 \%$ & 67 & $62.6 \%$ \\
\hline $\begin{array}{l}\text { Low socio-economic } \\
\text { status* }\end{array}$ & 30 & $66.7 \%$ & 9 & $40.9 \%$ & 24 & $61.5 \%$ & 57 & $64.8 \%$ \\
\hline \multicolumn{9}{|l|}{$\begin{array}{l}\text { DSM-IV Anxiety } \\
\text { Diagnosis (Lifetime) }\end{array}$} \\
\hline GAD & - & - & 11 & $42.3 \%$ & - & - & 84 & $75.0 \%$ \\
\hline Panic Disorder & - & - & 1 & $3.8 \%$ & - & - & 8 & $7.1 \%$ \\
\hline Separation anxiety & - & - & 11 & $42.3 \%$ & - & - & 38 & $33.9 \%$ \\
\hline Social anxiety & - & - & 11 & $42.3 \%$ & - & - & 46 & $41.1 \%$ \\
\hline \multicolumn{9}{|c|}{$\begin{array}{l}\text { Other DSM-IV KSADS-PL } \\
\text { Diagnoses (Lifetime) }\end{array}$} \\
\hline ADHD & 17 & $30.4 \%$ & 6 & $23.1 \%$ & 12 & $25.0 \%$ & 28 & $25.0 \%$ \\
\hline Depression & 7 & $12.5 \%$ & 4 & $16.0 \%$ & 5 & $10.4 \%^{a}$ & 30 & $27.3 \%^{\mathrm{b}}$ \\
\hline ODD & 9 & $16.1 \%$ & 3 & $11.5 \%$ & 10 & $20.8 \%$ & 16 & $14.3 \%$ \\
\hline Enuresis & 3 & $5.4 \%$ & 0 & $0 \%$ & 4 & $8.3 \%$ & 14 & $12.5 \%$ \\
\hline Encopresis & 1 & $1.8 \%$ & 0 & $0 \%$ & 0 & $0 \%$ & 2 & $1.8 \%$ \\
\hline Tic disorder & 3 & $5.4 \%$ & 4 & $15.4 \%$ & 2 & $4.2 \%$ & 8 & $7.2 \%$ \\
\hline OCD† & 2 & $3.6 \%$ & 0 & $0 \%$ & 0 & $0 \%$ & 3 & $2.7 \%$ \\
\hline PTSD $†$ & 0 & $0 \%$ & 0 & $0 \%$ & 1 & $2.1 \%$ & 9 & $8.1 \%$ \\
\hline Specific phobia† & 13 & $23.2 \%^{\mathrm{a}}$ & 14 & $53.8 \%^{a}$ & 5 & $10.4 \%^{a}$ & 52 & $46.4 \%^{\mathrm{b}}$ \\
\hline Conduct Disorder & 5 & $8.9 \%$ & 0 & $0 \%$ & 1 & $2.1 \%$ & 1 & $0.9 \%$ \\
\hline Mental retardation*** & 0 & $0 \%$ & 1 & $3.8 \%$ & 3 & $6.3 \%$ & 3 & $2.7 \%$ \\
\hline Clinical scores & Mean & SD & Mean & $\mathrm{SD}$ & Mean & $\mathrm{SD}$ & Mean & $\mathrm{SD}$ \\
\hline SCARED & $18.73^{\mathrm{a}}$ & 7.15 & $22.59^{b}$ & 4.45 & $38.50^{a}$ & 7.11 & $41.38^{b}$ & 7.92 \\
\hline MASC* & $35.22^{a}$ & 15.93 & $34.92^{b}$ & 11.91 & 46.72 & 14.20 & 58.83 & 13.92 \\
\hline $\mathrm{CDI}{ }^{*}$ & 7.13 & 6.23 & 5.89 & 2.14 & $5.30^{a}$ & 7.54 & $11.04^{b}$ & 6.50 \\
\hline
\end{tabular}

Abbreviations: $A D H D$, Attention Deficit/Hyperactivity Disorder; ODD, Oppositional Defiant Disorder; OCD, Obsessive Compulsive Disorder; GAD, Generalized Anxiety Disorder; PTSD, Post-traumatic Stress Disorder; SCARED, Screen for Children and Anxiety Related Emotional Disorders; MASC, Multidimensional Anxiety Scale for Children; CDI, Childood Depression Inventory.

Note: Bipolar disorder, Psychotic disorders, Anorexia, Bulimia, Tobacco dependence, Alcohol abuse and dependence, substance abuse and dependence and pervasive developmental disorders were not shown since frequency in the sample was lower than $3 \%$.

t Specific phobia, OCD and PTSD diagnosis were not considered for the "any anxiety diagnosis" group.

*Missing data.

*** Mental retardation was defined using a probability method based on clinical suspicion.

Different letters $(a, b)$ indicated statistical significant results $(p$-value $<0.05)$.

relation between ADHD and SCARED scores, the estimated prevalence of lifetime ADHD in our sample would be $23 \%$, greatly exceeding the worldwide estimated prevalence of $5 \% .{ }^{37}$ Therefore, it seems that our sample has a larger number of individuals seeking treatment for ADHD (as well as ODD) unbalancing the case numbers that attended diagnostic assessment.

There were no differences between anxious and non-anxious groups in terms of age, gender and socioeconomic status. The association between anxiety disorders and socioeconomic characteristics is controversial: ${ }^{3}$ although there is some evidence favoring a positive association, ${ }^{38}$ there are studies suggesting more complex relationships between poverty and mental disorders. ${ }^{39}$ Females are twice as likely as males to develop anxiety disorders, ${ }^{38,40}$ however some studies have shown that this sex difference, with respect to prevalence, is small in childhood and increases with age. ${ }^{41}$

Small- to medium-sized research centers frequently delineate research projects that aim to address one specific research question. Although this design brings some advantages (e.g. a more specific control for confounders, for example), it generally results in a lonely 
process of scientific exploration, is very expensive and does not provide data for testing further hypotheses of a complex phenomenon such as psychiatric disorders. Therefore, a collaborative work that considers different theoretical approaches is a notable advantage.

A randomized clinical trial (RCT) followed by evaluations of treated cases was planned in the PROTAIA project in order to evaluate treatment efficacy with previously tested medication. ${ }^{42}$ However, due to the low participation rate of the subjects in the clinical evaluations, even after several attempts to make contact, this treatment research plan could not be implemented. This situation reflects one of the difficulties in carrying out research in community settings, especially concerning anxiety disorders. Although anxiety disorders are responsible for disability and suffering, few subjects agreed to participate in the study, in which CBGT was offered at no cost.

The development of validated and effective techniques of group CBT is needed, especially when looking from a public health perspective. Very few studies have been published in the country evaluating the effectiveness of psychotherapeutic approaches in childhood. If these protocols prove their effectiveness, CBT could have a major role in the treatment of anxious children and adolescents in the public health system. Research in this area is essential given that protocols from other parts of the world without any type of cultural adaptation are unlikely to be effective for the Brazilian population. It is known that strategies for coping with anxiety disorders are very dependent on the cultural environment. ${ }^{43}$

The whole design of our protocol has some limitations. First, study participation in the diagnostic phase was low compromising some of the clinical profile of our sample. It was thought that perhaps more phobic subjects were less likely to attend the diagnostic interview. Second, $75^{\text {th }}$ percentile has shown a low sensitivity and therefore more severe cases of anxiety could be over-represented in our sample since prevalence rates could not be adjusted for complex samples. Third, the method of selection using the SCARED is intrinsically related to scale performance and this scale is under the process of validation. However, there are no reliable scales to measure this specific construct of anxiety disorders for the Brazilian population. Otherwise, this is the first study (to the authors' knowledge) to evaluate a sample specifically in order to investigate symptoms of anxiety disorders in a Brazilian population with a probabilistic care, and to include several other clinical, nutritional and biological measures.

\section{Conclusion}

Future perspectives for the PROTAIA group include a neuroimaging study and the inclusion of inflammatory and biological markers in the blood samples. In addition, this paper aims to describe the preliminary results as well as to allow research collaboration with other emerging groups ${ }^{44}$ that share research interests and similar research protocols. The PROTAIA Project is a promising research project that can contribute to the knowledge of the relationship between anxiety disorders and anxiety-related phenotypes with several genetic and environmental risk factors.

\section{Acknowledgements}

We thank Luis Augusto Paim Rohde, PhD, Maria Angélica Nunes, PhD and Sandra Fuchs, PhD for their important contributions during the design phase of this project. We also thank the Centro Colaborador em Alimentação e Nutrição Escolar (CECANE-UFRGS) and Fundo Nacional para o Desenvolvimento da Educação do Ministério da Educação (FNDE) research teams.

$191 ・$ Revista Brasileira de Psiquiatria • vol $33 \bullet n^{\circ} 2 \cdot$ jun2011 


\section{Disclosures}

\begin{tabular}{|c|c|c|c|c|c|c|c|}
\hline $\begin{array}{l}\text { Writing group } \\
\text { member }\end{array}$ & Employment & $\begin{array}{c}\text { Research } \\
\text { grant }^{1}\end{array}$ & $\begin{array}{c}\text { Other research grant } \\
\text { or medical } \\
\text { continuous } \\
\text { education }\end{array}$ & $\begin{array}{l}\text { Speaker's } \\
\text { honoraria }\end{array}$ & $\begin{array}{l}\text { Ownership } \\
\text { interest }\end{array}$ & $\begin{array}{l}\text { Consultant/ } \\
\text { Advisory } \\
\text { board }\end{array}$ & Other $^{3}$ \\
\hline $\begin{array}{l}\text { Giovanni } \\
\text { Abrahão Salum }\end{array}$ & - & $\begin{array}{c}\text { CAPES } \\
\text { CNPq } \\
\text { FIPE-HCPA } \\
\text { FAPERGS }\end{array}$ & - & - & - & - & - \\
\hline $\begin{array}{l}\text { Luciano } \\
\text { Rassier Isolan }\end{array}$ & - & $\begin{array}{l}\text { CNPq } \\
\text { FIPE-HCPA } \\
\text { FAPERGS }\end{array}$ & - & - & - & - & - \\
\hline $\begin{array}{l}\text { Vera Lúcia } \\
\text { Bosa }\end{array}$ & $\begin{array}{l}\text { UFRGS- } \\
\text { HCPA }\end{array}$ & $\begin{array}{l}\text { CNPq } \\
\text { FIPE-HCPA } \\
\text { FAPERGS }\end{array}$ & - & - & - & - & - \\
\hline $\begin{array}{l}\text { Andrea Goya } \\
\text { Tocchetto }\end{array}$ & - & $\begin{array}{l}\text { CNPq } \\
\text { FIPE-HCPA } \\
\text { FAPERGS }\end{array}$ & - & - & - & - & - \\
\hline $\begin{array}{l}\text { Stefania Pigatto } \\
\text { Teche }\end{array}$ & - & $\begin{array}{l}\text { CNPq } \\
\text { FIPE-HCPA } \\
\text { FAPERGS }\end{array}$ & - & - & - & - & - \\
\hline llaine Schuch & $\begin{array}{l}\text { UFRGS- } \\
\text { HCPA }\end{array}$ & $\begin{array}{l}\text { CNPq } \\
\text { FIPE-HCPA } \\
\text { FAPERGS }\end{array}$ & - & - & - & - & - \\
\hline $\begin{array}{l}\text { Jandira } \\
\text { Rahmeier } \\
\text { Costa }\end{array}$ & - & $\begin{array}{l}\text { CNPq } \\
\text { FIPE-HCPA } \\
\text { FAPERGS }\end{array}$ & - & - & - & - & - \\
\hline $\begin{array}{l}\text { Marianna de } \\
\text { Abreu Costa }\end{array}$ & - & $\begin{array}{l}\text { CNPq } \\
\text { FIPE-HCPA } \\
\text { FAPERGS }\end{array}$ & - & - & - & - & - \\
\hline $\begin{array}{l}\text { Rafaela Behs } \\
\text { Jarros }\end{array}$ & - & $\begin{array}{l}\text { CNPq } \\
\text { FIPE-HCPA } \\
\text { FAPERGS }\end{array}$ & - & - & - & - & - \\
\hline $\begin{array}{l}\text { Maria Augusta } \\
\text { Mansur }\end{array}$ & - & $\begin{array}{l}\text { CNPq } \\
\text { FIPE-HCPA } \\
\text { FAPERGS }\end{array}$ & - & - & - & - & - \\
\hline Daniela Knijnik & - & $\begin{array}{l}\text { CNPq } \\
\text { FIPE-HCPA } \\
\text { FAPERGS }\end{array}$ & - & - & - & - & - \\
\hline $\begin{array}{l}\text { Estácio Amaro } \\
\text { Silva }\end{array}$ & - & $\begin{array}{c}\text { CAPES } \\
\text { CNPq } \\
\text { FIPE-HCPA } \\
\text { FAPERGS }\end{array}$ & - & - & - & - & - \\
\hline $\begin{array}{l}\text { Christian } \\
\text { Kieling }\end{array}$ & - & $\begin{array}{l}\text { CNPq } \\
\text { FIPE-HCPA } \\
\text { FAPERGS }\end{array}$ & - & - & - & - & - \\
\hline $\begin{array}{l}\text { Maria Helena } \\
\text { Oliveira }\end{array}$ & - & $\begin{array}{l}\text { CNPq } \\
\text { FIPE-HCPA } \\
\text { FAPERGS }\end{array}$ & - & - & - & - & - \\
\hline Elza Medeiros & - & $\begin{array}{l}\text { CNPq } \\
\text { FIPE-HCPA } \\
\text { FAPERGS }\end{array}$ & - & - & - & - & - \\
\hline $\begin{array}{l}\text { Andressa } \\
\text { Bortoluzzi }\end{array}$ & - & $\begin{array}{c}\text { CAPES } \\
\text { CNPq } \\
\text { FIPE-HCPA } \\
\text { FAPERGS }\end{array}$ & - & - & - & - & - \\
\hline
\end{tabular}

(TO CONTINUE) 
(CONTINUATION)

\begin{tabular}{|c|c|c|c|c|c|c|c|}
\hline $\begin{array}{l}\text { Writing group } \\
\text { member }\end{array}$ & Employment & $\begin{array}{l}\text { Research } \\
\text { grant }^{1}\end{array}$ & $\begin{array}{c}\text { Other research grant } \\
\text { or medical } \\
\text { continuous } \\
\text { education }^{2}\end{array}$ & $\begin{array}{l}\text { Speaker's } \\
\text { honoraria }\end{array}$ & $\begin{array}{l}\text { Ownership } \\
\text { interest }\end{array}$ & $\begin{array}{l}\text { Consultant/ } \\
\text { Advisory } \\
\text { board }\end{array}$ & Other $^{3}$ \\
\hline $\begin{array}{l}\text { Rudineia } \\
\text { Toazza }\end{array}$ & - & $\begin{array}{c}\text { CAPES } \\
\text { CNPq } \\
\text { FIPE-HCPA } \\
\text { FAPERGS }\end{array}$ & - & - & - & - & - \\
\hline Carolina Blaya & UFCSPA & $\begin{array}{l}\text { CNPq } \\
\text { FIPE-HCPA } \\
\text { FAPERGS }\end{array}$ & - & - & - & - & - \\
\hline $\begin{array}{l}\text { Sandra } \\
\text { Leistner-Segal }\end{array}$ & $\begin{array}{l}\text { UFRGS- } \\
\text { HCPA }\end{array}$ & $\begin{array}{l}\text { CNPq } \\
\text { FIPE-HCPA } \\
\text { FAPERGS }\end{array}$ & - & - & - & - & - \\
\hline $\begin{array}{l}\text { Jerusa } \\
\text { Fumagalli de } \\
\text { Salles }\end{array}$ & UFRGS & $\begin{array}{l}\text { CNPq } \\
\text { FIPE-HCPA } \\
\text { FAPERGS }\end{array}$ & - & - & - & - & - \\
\hline $\begin{array}{l}\text { Patrícia Pelufo } \\
\text { Silveira }\end{array}$ & $\begin{array}{l}\text { UFRGS- } \\
\text { HCPA }\end{array}$ & $\begin{array}{l}\text { CNPq } \\
\text { FIPE-HCPA } \\
\text { FAPERGS }\end{array}$ & - & - & - & - & - \\
\hline $\begin{array}{l}\text { Marcelo } \\
\text { Zubaran } \\
\text { Goldani }\end{array}$ & $\begin{array}{l}\text { UFRGS- } \\
\text { HCPA }\end{array}$ & $\begin{array}{l}\text { CNPq } \\
\text { FIPE-HCPA } \\
\text { FAPERGS }\end{array}$ & - & - & - & - & - \\
\hline Elizeth Heldt & $\begin{array}{l}\text { UFRGS- } \\
\text { HCPA }\end{array}$ & $\begin{array}{l}\text { CNPq } \\
\text { FIPE-HCPA } \\
\text { FAPERGS }\end{array}$ & - & - & - & - & - \\
\hline $\begin{array}{l}\text { Gisele Gus } \\
\text { Manfro }\end{array}$ & $\begin{array}{l}\text { UFRGS- } \\
\text { HCPA }\end{array}$ & $\begin{array}{l}\text { CNPq } \\
\text { FIPE-HCPA } \\
\text { FAPERGS }\end{array}$ & - & - & - & - & Roche* \\
\hline
\end{tabular}

* Modest

** Significant

*** Significant: Amounts given to the author's institution or to a colleague for research in which the author has participation, not directly to the author.

Note: UFRGS-HCPA = Universidade Federal do Rio Grande do Sul-Hospital de Clínicas de Porto Alegre; UFCSPA = Universidade Federal de Ciências da Saúde de Porto Alegre; CAPES = Coordenação de Aperfeiçoamento de Pessoal de Nível Superior; CNPq = Conselho Nacional de Desenvolvimento Científico e Tecnológico; FIPE-HCPA = Fundo de Incentivo à Pesquisa e Eventos-Hospital de Clínicas de Porto Alegre, FAPERGS = Fundação de Amparo à Pesquisa do Estado do Rio Grande do Sul.

For more information, see Instructions for Authors.

\section{References}

1. Kessler RC, Angermeyer M, Anthony JC, DE Graaf R, Demyttenaere K, Gasquet I, DE Girolamo G, Gluzman S, Gureje O, Haro JM, Kawakami N Karam A, Levinson D, Medina Mora ME, Oakley Browne MA, Posada-Villa J, Stein DJ, Adley Tsang CH, Aguilar-Gaxiola S, Alonso J, Lee S, Heeringa S, Pennell BE, Berglund P, Gruber MJ, Petukhova M, Chatterji S, Ustün TB. Lifetime prevalence and age-of-onset distributions of mental disorders in the World Health Organization's World Mental Health Survey Initiative. World Psychiatry. 2007;6(3):168-76

2. Kessler RC, Berglund P, Demler O, Jin R, Merikangas KR, Walters EE. Lifetime prevalence and age-of-onset distributions of DSM-IV disorders in the National Comorbidity Survey Replication. Arch Gen Psychiatry. 2005;62(6):593-602.

3. Beesdo K, Knappe S, Pine DS. Anxiety and anxiety disorders in children and adolescents: developmental issues and implications for DSM-V. Psychiatr Clin North Am. 2009;32(3):483-524.

4. Kim-Cohen J, Caspi A, Moffitt TE, Harrington H, Milne BJ, Poulton R. Prior juvenile diagnoses in adults with mental disorder: developmental follow-back of a prospective-longitudinal cohort. Arch Gen Psychiatry. 2003;60(7):709-17.

5. Smoller JW, Gardner-Schuster E, Misiaszek M. Genetics of anxiety: would the genome recognize the DSM? Depress Anxiety. 2008;25(4):368-77.
6. American Psychiatric Association - APA. Diagnostic and statistical manual of mental disorders. 3rd ed. Washington, D.C: American Psychiatric Association; 1980.

7. Phillips KA, Friedman MJ, Stein DJ, Craske M. Special DSM-V issues on anxiety, obsessive-compulsive spectrum, posttraumatic, and dissociative disorders. Depress Anxiety. 2010;27(2):91-2.

8. Hollander E, Braun A, Simeon D. Should OCD leave the anxiety disorders in DSM-V? The case for obsessive compulsive-related disorders. Depress Anxiety. 2008;25(4):317-29.

9. Resick PA, Miller MW. Posttraumatic stress disorder: anxiety or traumatic stress disorder? J Trauma Stress. 2009;22(5):384-90

10. Wittchen HU, Lieb R, Pfister H, Schuster P. The waxing and waning of mental disorders: evaluating the stability of syndromes of mental disorders in the population. Compr Psychiatry. 2000;41(2 Suppl 1):122-32.

11. Wittchen H, Lieb R, Schuster P. When is onset? Investigations into early developmental stages of anxiety and depressive disorders. In: Rapoport J, editor. Childhood onset of "adult" psychopathology Clinical and research advances. Washington, DC: American Psychiatric Press; 1999. p.259-302.

12. Maughan B, Kim-Cohen J. Continuities between childhood and adult life. Br J Psychiatry. 2005;187:301-3.

$193 ・$ Revista Brasileira de Psiquiatria ・ vol $33 \bullet n^{\circ} 2 \cdot$ jun2011 
13. Rutter M, Kim-Cohen J, Maughan B. Continuities and discontinuities in psychopathology between childhood and adult life. J Child Psychol Psychiatry. 2006;47(3-4):276-95.

14. Cicchetti D, Toth SL. The past achievements and future promises of developmental psychopathology: the coming of age of a discipline. J Child Psychol Psychiatry. 2009;50(1-2):16-25.

15. Salum GA, Polanczyk GV, Miguel EC, Rohde LA. Effects of childhood development on late-life mental disorders. Curr Opin Psychiatry. 2010;23(6):498-503. 16. Anderson SE, Cohen P, Naumova EN, Must A. Association of depression and anxiety disorders with weight change in a prospective community-based study of children followed up into adulthood. Arch Pediatr Adolesc Med. 2006;160(3):285-91.

17. Birmaher B, Brent DA, Chiappetta L, Bridge J, Monga S, Baugher M. Psychometric properties of the Screen for Child Anxiety Related Emotional Disorders (SCARED): a replication study. J Am Acad Child Adolesc Psychiatry. 1999;38(10):1230-6.

18. Birmaher B, Khetarpal S, Brent D, Cully M, Balach L, Kaufman J, Neer SM. The Screen for Child Anxiety Related Emotional Disorders (SCARED): scale construction and psychometric characteristics. J Am Acad Child Adolesc Psychiatry. 1997;36(4):545-53

19. Kendall PC, Flannery-Schroeder E. Cognitive-behavioral therapy for anxious children: therapist manual for group treatment. 3rd ed. Pennsylvania: Workbook Publishing; 2006.

20. Kendall PC, Hedtke K. The coping cat workbook. 2rd ed. Pennsylvania: Workbook Publishing; 2006

21. Shortt AL, Barrett PM, Fox TL. Evaluating the FRIENDS program: a cognitivebehavioral group treatment for anxious children and their parents. $J$ Clin Child Psychol. 2001;30(4):525-35.

22. Hale WW, 3rd, Crocetti E, Raaijmakers QA, Meeus WH. A meta-analysis of the cross-cultural psychometric properties of the Screen for Child Anxiety Related Emotional Disorders (SCARED). J Child Psychol Psychiatry. 2011;52(1):80-90.

23. World Health Organization - WHO. Physical status: the use and interpretation of anthropometry. Report of a WHO Expert Committee. Technical Report Series 854. Geneva: World Health Organization; 1995.

24. Frisancho AR. Triceps skin fold and upper arm muscle size norms for assessment of nutrition status. Am J Clin Nutr. 1974;27(10):1052-8.

25. Taylor RW, Jones IE, Williams SM, Goulding A. Evaluation of waist circumference, waist-to-hip ratio, and the conicity index as screening tools for high trunk fat mass, as measured by dual-energy X-ray absorptiometry, in children aged 3-19 y. Am J Clin Nutr. 2000;72(2):490-5.

26. Frisancho AR. New norms of upper limb fat and muscle areas for assessment of nutritional status. Am J Clin Nutr. 1981;34(11):2540-5.

27. Tanner JM. Growth at adolescence. 2nd ed. Oxford: Blackwell Scientific Publications; 1962.

28. Abu Khaled M, McCutcheon MJ, Reddy S, Pearman PL, Hunter GR, Weinsier RL. Electrical impedance in assessing human body composition: the BIA method. Am J Clin Nutr. 1988;47(5):789-92.

29. Bouchard C, Treblay A, Leblanc C, Lortie G, Savard R, E Thériault G. A method to assess energy expenditure in children and adults. Am J Clin Nutr. 1983;37(3):461-7.

30. Willett WC. Nutritional epidemiology. 2nd ed. New York: Oxford University Press; 1998

31. Slater B, Philippi ST, Fisberg RM, Latorre MRDO. Validation of a semiquantitative adolescents food frequency questionnaire applied at a public school in São Paulo, Brazil. Eur J Clin Nutr. 2003;57(5):629-35.

32. Simon E, Bogels SM. Screening for anxiety disorders in children. Eur Child Adolesc Psychiatry. 2009;18(10):625-34.

33. Fleitlich-Bilyk B, Goodman R. Prevalence of child and adolescent psychiatric disorders in southeast Brazil. J Am Acad Child Adolesc Psychiatry. 2004;43(6):72734

34. Merikangas KR, He JP, Burstein M, Swanson SA, Avenevoli S, Cui L, Benjet C, Georgiades K, Swendsen J. Lifetime prevalence of mental disorders in U.S. adolescents: results from the National Comorbidity Survey Replication--Adolescent Supplement (NCS-A). J Am Acad Child Adolesc Psychiatry. 2010;49(10):980-9. 35. Krueger RF. The structure of common mental disorders. Arch Gen Psychiatry. 1999;56(10):921-6.
36. Pliszka SR. Patterns of psychiatric comorbidity with attention-deficit/hyperactivity disorder. Child Adolesc Psychiatr Clin NAm. 2000;9(3):525-40, vii.

37. Polanczyk G, de Lima MS, Horta BL, Biederman J, Rohde LA. The worldwide prevalence of ADHD: a systematic review and metaregression analysis. $A m J$ Psychiatry. 2007;164(6):942-8.

38. Wittchen HU, Nelson CB, Lachner G. Prevalence of mental disorders and psychosocial impairments in adolescents and young adults. Psychol Med. 1998;28(1):109-26.

39. Costello EJ, Compton SN, Keeler G, Angold A. Relationships between poverty and psychopathology: a natural experiment. JAMA. 2003;290(15):2023-9.

40. Pine DS, Cohen P, Gurley D, Brook J, Ma Y. The risk for early-adulthood anxiety and depressive disorders in adolescents with anxiety and depressive disorders. Arch Gen Psychiatry. 1998;55(1):56-64.

41. Craske M. Origins of phobias and anxiety disorders: why more women than men? Amsterdam: Elsevier; 2003.

42. Isolan L, Pheula G, Salum GA Jr, Oswald S, Rohde LA, Manfro GG. An open-label trial of escitalopram in children and adolescents with social anxiety disorder. J Child Adolesc Psychopharmacol. 2007 Dec;17(6):751-60.

43. Aguilera A, Garza MJ, Munoz RF. Group cognitive-behavioral therapy for depression in Spanish: culture-sensitive manualized treatment in practice. J Clin Psychol. 2010;66(8):857-67.

44. Salum GA, Blaya C, Manfro GG, Segal J, Leistner-Segal S. Emerging research groups studying Brazilian psychiatric genetics. Rev Bras Psiquiatr. 2010;32(1):91-4. 45. Olweus D. Bullying at school: What we know and what we can do. Oxford: Blackwell; 1993.

46. Nansel TR, Overpeck M, Pilla RS, Ruan WJ, Simons-Morton B, Scheidt P. Bullying behaviors among US youth: prevalence and association with psychosocial adjustment. JAMA. 2001;285(16):2094-100.

47. Goodman R. The Strengths and Difficulties Questionnaire: a research note. J Child Psychol Psychiatry. 1997;38(5):581-6.

48. Goodman R, Meltzer H, Bailey V. The Strengths and Difficulties Questionnaire: a pilot study on the validity of the self-report version. Eur Child Adolesc Psychiatry. 1998;7(3):125-30.

49. March JS, Parker JD, Sullivan K, Stallings P, Conners CK. The Multidimensional Anxiety Scale for Children (MASC): factor structure, reliability, and validity. J Am Acad Child Adolesc Psychiatry. 1997;36(4):554-65.

50. Kovacs M, Beck AT. An empirical-clinical approach toward a definition of childhood depression. In: Schulterbrandt JG, Raskin A, editors. Depression in childhood: diagnosis, treatment, and conceptual models. New York: Raven Press; 1977. p.1-25.

51. Golfeto JH, Veiga MH, Sousa L, Barbeira C. Propriedades Psicométricas do Inventário de Depressão Infantil (CDI) aplicado em uma amostra de escolares de Ribeirão Preto. Rev Psiquiatr Clín. 2002;29:66-70.

52. Gouveia VV, Barbosa GA, Almeida HJF, Gaião AA. Inventário de Depressão Infantil - CDI: Estudo de adaptação com escolares de João Pessoa. J Bras Psiquiatr. 1995;44:345-9.

53. Wathier JL, Dell'Aglio DD, Bandeira DR. Análise fatorial do Inventário de Depressão Infantil (CDI) em amostra de jovens brasileiros. Aval Psicol. 2008;7(1):75-84

54. Edwards TC, Huebner CE, Connell FA, Patrick DL. Adolescent quality of life, part I: conceptual and measurement model. J Adolesc. 2002;25(3):275-86.

55. Patrick DL, Edwards TC, Topolski TD. Adolescent quality of life, part II: initial validation of a new instrument. J Adolesc. 2002;25(3):287-300.

56. Silverman WK, Ginsburg GS, Goedhart AW. Factor structure of the childhood anxiety sensitivity index. Behav Res Ther. 1999;37(9):903-17.

57. Tarshis TP, Huffman LC. Psychometric properties of the Peer Interactions in Primary School (PIPS) Questionnaire. J Dev Behav Pediatr. 2007;28(2):125-32.

58. Muris P, Merckelbach H, Wessel I, van de Ven M. Psychopathological correlates of self-reported behavioural inhibition in normal children. Behav Res Ther. 1999;37(6):575-84.

59. Reznick JS, Hegeman IM, Kaufman ER, Woods SW, Jacobs M. Retrospective and concurrent self-report of behavioral inhibition and their relation to adult mental health. Dev Psychopathol. 1992;4:301-21.

60. Bernstein DP, Stein JA, Newcomb MD, Walker E, Pogge D, Ahluvalia T, Stokes J, Handelsman L, Medrano M, Desmond D, Zule W. Development and 
validation of a brief screening version of the Childhood Trauma Questionnaire. Child Abuse Negl. 2003;27(2):169-90.

61. Grassi-Oliveira R, Stein LM, Pezzi JC. Translation and content validation of the Childhood Trauma Questionnaire into Portuguese language. Rev Saude Publica. 2006;40(2):249-55.

62. Wagnild GM, Young HM. Development and psychometric evaluation of the Resilience Scale. J Nurs Meas. 1993;1(2):165-78.

63. Pesce RP, Assis SG, Avanci JQ, Santos NC, Malaquias JV, Carvalhaes R. Adaptação transcultural, confiabilidade e validade da escala de resiliência. Cad Saúde Pública. 2005;21(2):436-48.

64. The Alcohol, Smoking and Substance Involvement Screening Test (ASSIST): development, reliability and feasibility. Addiction. 2002;97(9):1183-94.

65. Henrique IF, De Micheli D, Lacerda RB, Lacerda LA, Formigoni ML. [Validation of the Brazilian version of Alcohol, Smoking and Substance Involvement Screening Test (ASSIST)]. Rev Assoc Med Bras. 2004;50(2):199-206.

66. Kaufman J, Birmaher B, Brent D, Rao U, Flynn C, Moreci P, Williamson D, Ryan N. Schedule for Affective Disorders and Schizophrenia for School-Age Children-Present and Lifetime Version (K-SADS-PL): initial reliability and validity data. J Am Acad Child Adolesc Psychiatry. 1997;36(7):980-8.

67. Beck AT, Brown G, Epstein N, Steer RA. An inventory for measuring clinical anxiety: psychometric properties. J Consult Clin Psychol. 1988;56(6):893-7.

68. Cunha J. Manual da versão em português das Escalas Beck. São Paulo: Casa do Psicólogo; 2001. 171p.

69. Beck AT, Steer RA, Garbin MG. Psychometric properties of the Beck depression inventory: Twenty-five years of evaluation. Clin Psychol Rev. 1988(8):77-100.

70. Gorenstein C, Andrade L. Inventário de depressão de Beck: Propriedades psicométricas da versão em português. Rev Psiquiatr Clín. 1998;25(5):245-50.

71. Gorenstein C, Andrade L. Validation of a portuguese version of Beck depression inventory and the state-trait anxiety inventory in Brazilian subjects. Braz J Med Biol Res. 1996;29(4):453-7.

72. Cloninger CR, Przybeck TR, Svrakic DM. The tridimensional personality questionnaire: U.S. normative data. Psychol Rep. 1991;69(3 Pt 1):1047-57.

73. Moos RH, Moos BS. Clinical applications of the family environment scale. In: EE F, editor. Marriage and family assessment. Beverly Hills: Sage; 1983. p.253-73.

74. Vianna VPT, Silva EA, Souza-Formigoni MLO. Versão em português da family environment scale: aplicação e validação. Rev Saúde Pública. 2007;41(3):419-26. 75. Hauck S, Schestatsky S, Terra L, Knijnik L, Sanchez P, Ceitlin LHF. Adaptação transcultural para o português brasileiro do Parental Bonding Instrument (PBI). Rev Psiquiatr RS. 2006;28(2):162-8.

76. Goncalves DM, Cloninger CR. Validation and normative studies of the Brazilian Portuguese and American versions of the Temperament and Character Inventory - Revised (TCI-R). J Affect Disord. 2010;124(1-2):126-33.

77. Wachleski C, Salum GA, Blaya C, Kipper L, Paludo A, Salgado AP, Manfro GG. Harm avoidance and self-directedness as essential features of panic disorder patients. Compr Psychiatry. 2008;49(5):476-81.

78. Spreen O, Strauss E. A compendium of neuropsychological test: administration, norms and commentary. New York: Oxford University Press; 2006.

79. Wechsler D. Wechsler Intelligence Scale for Children (WISC-III) - Manual. 3rd ed. San Antonio: Psychological Corporation; 1991.

80. Reitan RM, Wolfson D. The Halstead-Reitan Neuropsychology Battery: Theory and Clinical Interpretation, Tucson, AZ, Neuropsychology Press - (1995): "Category test and trail making test as measures of frontal lobe functions". Clin Neuropsychol. 1993;9:50-6.

81. Brickenkamp R. Teste d2: Atenção concentrada. São Paulo: CETEPP - Centro Editor de Testes e Pesquisas em Psicologia; 2000. p.1-94.

82. Smidts D. Development of executive processes in early childhood [tese]. Department of Psychology, Australia: University of Melbourne; 2003.

83. Heaton R, Chelune G, Talley J, Kay G, Curtis G. Wisconsin Card Sorting Test (WCST). Manual Revised and expanded. Odessa, FL: Psychological Assement Resources; 1993.

84. Rey A. Figuras complexas de Rey: Teste de cópia e de recuperação de memória de figuras geométricas complexas. Manual. Revisão técnica e tradução de Terezinha Rey e Lucia Cristina Fleury Franco; adaptação brasileira de Margareth da Silva Oliveira. São Paulo: Casa do Psicólogo; 1998-1999.
85. Malloy-Diniz LF, LasmarI VA, GazinelliI LS, FuentesI D, Salgado JV. The Rey auditory-verbal learning test: applicability for the Brazilian elderly population. Rev Bras Psiquiatr. 2007;29(4):324-9.

86. Ekman P, Friesen W. Pictures of facial affect. Palo Alto, CA: Consulting Psychologists Press; 1976.

$195 \bullet$ Revista Brasileira de Psiquiatria • vol $33 \bullet \mathrm{n}^{\circ} 2 \cdot$ jun2011 